\title{
Peran Pers Dalam Penegakan Hukum Ditinjau Dari Segi Undang-Undang Nomor 40 Tahun 1999 Tentang Pers
}

\author{
Satino $^{1}$, Iswahyuni², Surahmad ${ }^{3}$ \\ 1Fakultas Hukum Universitas Pamulang \\ Email: satino@upnvj.ac.id \\ 2 Fakultas Ilmu Sosial dan Ilmu Politik UPN Veteran Jakarta \\ Email: iswahyuni_upnvj@yahoo.co.id \\ ${ }^{3}$ Fakultas Hukum UPN Veteran Jakarta \\ Email: surahmad1970@gmail.com
}

\begin{abstract}
The constitution provides equal standing and equal rights between citizens. One form of equal rights is freedom of speech. One of them is the guarantee of press freedom. The press is a social institution and a vehicle of mass communication that carries out journalistic activities that include finding, acquiring, possessing, storing, processing, and conveying information both in the form of writing, sound, images, sounds and images, as well as data and graphics and in other forms using print media, electronic media, and all kinds of channels available. The problem in this paper is how the role and function of the press in enforcement and how the responsibility of the press and the code of ethics of the press are reviewed from Law No. 40 of 1999. The method used in this study is normative legal research. As for the conclusion in this study first that the Press is the fourth pillar of democracy after the executive, legislative and judiciary, the press as control over the three pillars and based its performance with check and balance. To be able to perform its role needs to be respected freedom of the press in conveying public information honestly and balanced. The second freedom of the Press is not absolute for the press alone, but to guarantee the rights of the public to obtain information. I
\end{abstract}

Keywords: The freedom of the Press, Freedom of speech

\begin{abstract}
Abstrak
Konsitusi memberikan kedudukan yang sama dan persamaan hak antar warga negara. Bentuk persamaan hak salah satunya adalah kebebasan menyampaikan pendapat. Dimana salah satunya adalah adanya jaminan kemerdekaan pers. Pers adalah lembaga sosial dan wahana komunikasi massa yang melaksanakan kegiatan jurnalistik yang meliputi mencari, memperoleh, memiliki, menyimpan, mengolah, dan menyampaikan informasi baik dalam bentuk tulisan, suara, gambar, suara dan gambar, serta data dan grafik maupun dalam bentuk lainnya dengan menggunakan media cetak, media elektronik, dan segala jenis saluran yang tersedia. Adapun yang menjadi permasalahan dalam tulisan ini adalah Bagaimana peran dan fungsi pers dalam penegakkan serta Bagaimana Tanggung Jawab Pers dan Kode Etik Pers ditinjau dari UU Nomor 40 Tahun 1999. Adapun metode yang digunakan dalam penelitian ini adalah penelitian hukum normatif. Adapun kesimpulan dalam penelitian ini pertama bahwa Pers merupakan pilar demokrasi keempat setelah eksekutif, legislatif dan yudikatif, pers sebagai kontrol atas ketiga pilar itu dan melandasi kinerjanya dengan check and balance. untuk dapat melakukan peranannya perlu dijunjung kebebasan pers dalam menyampaikan informasi publik secara jujur dan berimbang. Kedua kebebasan Pers bukan mutlak untuk pers semata, melainkan untuk menjamin hak-hak masyarakat untuk memperoleh informasi.
\end{abstract}

Kata kunci: Kebebasan Pers, Kebebasan berpendapat 


\section{Pendahuluan}

\subsection{Latar Belakang}

Dewasa ini perekonomian Indonesia mengalami perkembangan cukup pesat yang ditandai dengan adanya pembangunan nasional yang mulai merata, adanya kemajuan infrastruktur serta kini dunia perekonomian mulai memasuki era digital dan bersifat global. Pihak yang berperan sebagai pelaku ekonomi salah satunya adalah Perseroan Terbatas (PT). PT merupakan salah satu pilar penting pembangunan perekonomian nasional yang mampu memacu pembangunan nasional yang disusun bersama berdasar atas asas kekeluargaan. ${ }^{1}$ Manusia dan hukum adalah merupakan 2 (dua) hal yang tidak bisa dipisahkan dalam kehidupan di dunia ini. Hal ini dikarenakan tanpa sebuah hukum yang mengatur tingkah laku manusia maka terjadi kekacauan di dalam kehidupan manusia (masyarakat). Sifat bawaan manusia yang ingin selalu menang sendiri dan egois harus ditata dan diatur sedemikian rupa oleh hukum tanpa kecuali, agar tidak melanggar hak orang lain. Peran hukum yang begitu penting inilah yang selanjutnya oleh bangsa Indonesia dipatridi dalam pasal ayat (3) UUD 1945 yang menyebutkan bahwa negara Indonesia adalah negara hukum. Hal ini berarti bahwa seluruh warga negara dan aparat pemerintahan negara Indonesia dalam bertindak harus berdasarkan aturan hukum yang berlaku. Di dalam pasal 27 ayat (1) UUD 1945 juga disebutkan bahwa, segala warga negara bersamaan kedudukannya di dalam hukum dan pemerintahan dan wajib menjunjung hukum dan pemerintahan itu dengan tidak ada kecualinya. Maka bunyi pasal 27 (1) UUD 1945 adalah negara Indonesia menjamin equality before the law (persamaan dimuka hukum tanpa kecuali) dalam kehidupan berbangsa dan bernegara.

Bentuk persamaan hak, salah satunya adalah memberikan kebebebasan kepada warga negara dalam menyampaikan pendapat. Dimana salah satunya adalah adanya jaminan kemerdekaan pers. Istilah Pers berasal dari Bahasa Belanda, yang dalam Bahasa Inggris berarti Press. Secara harfiah pers berarti cetak dan secara maknawiah berarti penyiaran secara tercetak atau publikasi secara dicetak (printed publication)²Kemerdekaan pers merupakan salah satu wujud kedaulatan rakyat dan menjadi unsur yang sangat penting untuk menciptakan kehidupan bermasyarakat, berbangsa dan bernegara yang demokratis, sehingga kemerdekaan mengeluarkan pikiran dan pendapat sebagaimana tercantum dalam Pasal 28 Undnag-Undang Dasar 1945 harus dijamin Dalam rentang waktu peradaban manusia, Pers merupakan salah satu sarana perubahan dan kemajuan masyarakat dan negara. Hal ini dikarenakan pers berfungsi menyebarluaskan informasi, melakukan kontrol sosial yang konstruktif, menyalurkan aspirasi rakyat, dan meluaskan

${ }^{1}$ Lihat konsideran huruf c Undang-Undang Republik Indonesia Nomor 40 Tahun 2007 tentang Perseroan Terbatas.

2 Dahlan Surbakti, adalah alumnus Fakultas Hukum USU Medan dan Pascasarjana Ilmu Hukum Ekonomi (Reguler) Fakultas Hukum UI, kini Dosen Tetap Fakultas Hukum Universitas Bhayangkara Jakarta Raya dan Dosen Tidak Tetap di Beberapa PTS di Jakarta, serta Redaktur Senior Tabloid Duta Bangsa Jakarta 
komunikasi socsal dan partisipasi masyarakat. Demikian signifikansinya fungsi Pers maka seyogyanya Pers harus mendapat tempat dan perlakuan yang sama dalam mengembangkan jati dirinya.

Pers adalah lembaga sosial dan wahana komunikasi massa yang melaksanakan kegiatan jurnalistik yang meliputi mencari, memperoleh, memiliki, menyimpan, mengolah, dan menyampaikan informasi baik dalam bentuk tulisan, suara, gambar, suara dan gambar, serta data dan grafik maupun dalam bentuk lainnya dengan menggunakan media cetak, media elektronik, dan segala jenis saluran yang tersedia. Dalam Kamus Besar Bahasa Indonesia, Pers diartikan :

1. Usaha Percetakan dan Penerbitan.

2. Usaha pengumpulan data dan penyiaran berita.

3. Penyiaran berita melalui surat kabar, majalah, dan radio.

4. Orang yang bergerak dalam penyiaran berita.

5. Medum penyiaran berita sperti surat kabar, majalah, dan radio, televisi, dan film.

Pers mempunyai segi lain, bukan sekedar mencerminkan apa yang terjadi secara reaktif, secara paska kejadian, post facktum, tetapi melihat lebih dulu, merencanakan dan mengagendakan. Pers bukan saja riding the news, tetapi, sebutlah sekedar untuk membedakan, making the news, planning the news. Dari sisi inilah, pers dikatakan tidak sekedar terbawa oleh peristiwa dan masalah, tetapi semacam membuat, menentukan atau lebih proposional mempengaruhi agenda. Dlam Pasal 3 UU Nomor 40 Tahun 1999 bahwa pers mempunyai fungsi sebgai media informasi, pendidikan, hiburan, dan control sosial selain dari itu poers juga berfungsi sebagai lembaga ekonomi

\subsection{Rumusan Masalah}

Sebagai pijakan dan sekaligus juga sebagai pembatasan dalam pembahasan tulisan ini dikemukan rumusan masalah sebagai berikut:

1. Bagaimana peran dan fungsi pers dalam penegakkan hukum ditinjau dari UU Nomor 40 Tahun 1999 tentang Pers?

2. Bagaimana Tanggung Jawab Pers dan Kode Etik Pers ditinjau dari UU Nomor 40 Tahun 1999?

\section{Metode Penelitian}

Penelitian ini merupakan penelitian hukum normatif yang menggunakan bahanbahan hukum dan bahan-bahan non hukum dengan menggunakan metode pendekatan peraturan perundang-undangan.

\section{Hasil dan Pembahasan}

\subsection{Peran dan Fungsi Pers Dalam Penegakkan Hukum}

Sebelum membahas pokok permasalahan, perlu terlebih dahulu diuraikan pengertian mengenai emiten, penawaran umum, dan efek. Emiten adalah pihak yang melaku, Istilah pers sudah lazim diartikan sebagai surat kabar (news paper) atau majalah (magazine) sering pula dimasukkan pengertian wartawan di dalamnya ${ }^{3}$. Demikian

${ }^{3}$ Onong Uchyana Effendi, (2002), Ilmu Komunikasl (Teori dan Praktek), Bandung, Remaja Rasdakarya, Cet, XVI, hlm 145. 
signifikansinya fungsi Pers maka seyogyanya Pers harus mendapat tempat dan perlakuan yang sama dalam mengembangkan jati dirinya.

Fungsi pers menurut Pasal 3 Undang-undang Nomor 40 Tahun 1999 tentang Pers, membeda-bedakan fungsi pers, fungsi informasi, fungsi pendidikan, fungsi hiburan, fungsi kontrol, dan fungsi ekonomi (pasal 3). Adapun Fungsi informasi, fungsi ini mencakup fungsi menyampaikan (menyebarkan) informasi, dan fungsi menerima informasi. Media massa akan mensuplai masyarakatnya untuk dapat memasuki dunia yang dipilihnya. Materi informasi fiksional semacam musik akan membawa penggunanya ke dunia subyektif, sedang materi faktual sepe\{i berita (news) digunakan sebagai dasar memasuki dunia sosial empiris. Fungsi politik, fungsi ini mencakup fungsi kontrol, baik terhadap kekuasaan maupun dalam hubungan sosial (kemasyarakatan) dan fungsi menyalurkan, membentuk dan mengarahkan opini publik. Fungsi ekonomi, fungsi ini menempatkan pers, sebagai suatu bentuk usaha ekonomibaik untuk kepentingan ekonomi peserta usaha (mencari laba), maupun untuk kepentingan ekonomi masyarakat pada umumnya (menyediakan lapangan kerja atau ikut serta dalam tanggung jawab sosial perusahaan (corporate social responsibility) dan Fungsi Hiburan. Untuk menjalan fungsi-fungsi tersebut, ada beberapa karakteristik yang melekat pada pers.

1. Pers adalah pranata publik atau pranata sosial(social/public institution) karakteristik ini mengandung makna, meskipun disebut sebagai the fourth estate atau the fourth power, tetapi bukan substruktur dari organisasi penyelenggarakekuasaan kenegaraan (staatsorganisatie), dan pers semata-mata bekerja untuk dan berpihak pada kepentingan publik. Tentu saja, penylenggara (organisasi) kekuasaan negara, diharapkan juga untuk bekerja untuk kepentingan publik.

2. Pers harus bebas (merdeka) baik dalam makna independen maupun kebebasan berekpresi pada umumnya kebebasan berpendapat atau menyalurkan pendapat, perlu dicatat, yang paling esensial dalam kebebasanberpendapat adalah kebebasan berbeda pendapat.

Secara umum fungsi pers terkait dengan dua dimensi yaitu dimensi idialisme dan dimensi komersial. Dimensi idialisme berkenaan dengan buah pikiran, ide-ide dan pendapat umumatau induvidu yang terdpat pada atau dikelola oleh pers. Dalam fungsi ini tuas utama pers ada tiga yaitu : memberikan informasi, mendidik masyarakat dan menghibur atau memberikan hiburan bagi para pembaca, ketiga tugas ini harus terdapat pada pers, jika hanya memberikan informasi belaka pers akan akan tampakkering, ibarat sayur tanpa garam, meskipun bergizi rasanya kurang sedap. Pers juga diartikan sebagai the aggregate of publication issuing from the press, or the giving publication to one's sentiments and opinions though the medium ofprinting 4 . Demikian halnya bila pers hanya mendukung hiburan saja tidak memberikan hal berarti bagi pengembangan daya nalar pembaca. Secara normatif fungsi idealisme pers dijelaskan dalam perundang-undangan pers, seperti dalam UU/11/1966 dan UU/21/1982 pada pasal 2 ayat (1) UU/11/1966 disebutkan bahwa fungsi pers adalah sebagai alat revolusi dan merupakan media massa yang bersifat aktif, dinamis,

\footnotetext{
${ }^{4}$ Henry Chambel Black, Black Law Dictionary, St. Paul, Minn : West Publishing Co. hal. 822
} 
kreatif, informatoris, dan mempunyai fungsi kemasyarakatan, pendorong dan pemupuk daya pikir dan progresif meliputi segala perwujudan kehidupan masyarakat Indonesia. UU/21/1982 pasal 2 ayat (6) menyatakan bahwa dalam rangka meningkatkan peranannya dalam pembangunan, pers berfungsi sebagai penyebar informasi yang obyektif, menyalurkan aspirasi rakyat, meluaskan informasi yang obyektif, menyalurkan aspirasi rakyat, meluaskan komunikasi dan partisipasi masyarakat serta melakukan kontrol sosial yang konstruktif. Dalam hal ini diperlukan interaksi positif antara pemerintah, pers dan masyarakat. Fungsi pers menurut UU/40/1999 sebagaimana telah dijelaskan pada pasal 3 ayat (1) dan (2) adalah pers nasional mempunyai fungsi sebagai media informasi, pendidikan, hiburan, kontrol sosial, dan sebagai lembaga ekonomi. Dalam UU/40/1999 secara tegas disebutkan fungsi idealisme dan komersiel pers, berbeda dengan UU/11/1966 dan UU/21/1982 yang menekankan fungsi persdari isi idealismenya saja.

Bila dikaitkan antara fungsi pers dan penegakkan hukum. Bahwa penegakan hukum akan selalu terkait dengan dengan proses pembentukan dan interpretasi. Dengan demikian, setiap kali seorang pejabat menegakkan hukum, bukanlah semata-mata memperhatikan bunyi hukum tetapi juga yang berkaitan dengan proses pembentukan hukum yang akan diterapkan, juga akan meliputi hal-hal seperti alasan-alasan, latar belakang, rumusan, maksud dan tujuan dll yang akan mengantarka kepada penegakan hukum yang tepat dan benar.

Tiga aspek hubungan pers dengan penegak hukum

a. Pers sebagai obyek penegakan hukum atau yang terkena penegakan hukum

b. Pers sebagai fasilitator penegakan hukum

c. Pers sebagai penghambat penegan hukum

1. Pers sebagai obyek penegakan hukum atau sebagai yang terkena penegakan hukum. Pers menjadi obyek penegakan hukum karena pers adalah subyek hukum, pers sebagai subyek hukum dapat mengenai pelaku pers pers (wartawan, redaktur, pemilik pers) atau pers sebagai lembaga.penegakan hukum terhadap pers terjadi karena pers melakukan pelanggaran hukum, melakukan perbuatan melawan hukum yang dapat meliputi pelanggaran yang bersifat pidana, keperataan, atau administrasi. Pelanggaran pidana dapat meliputi perbuatan seperti pencemaran nama baik, atau fitnah atau melanggar privacy, trespassing, menyebarkan rahasia negara. Dimasa penjajahan, kita mengenal sebutan "delik hukum" seperti "perbuatan menyebarkan (rasa) permusuhan terhadap penguasa (haatzai artikelen). Sebenarnya ketentuan-ketentua diatas tadi berlaku pada setiap subyekhukum, tidak hanya terbaas pada pers.

2. Pers sebagai fasilitator penegakan hukum, salah satu fungsi pers sebagai fungsi tertua, adalah menyediakan atau menyampaikan informasi kepada publik. Salah satu informasi adalah berbagai peristiwa hukum, hubungan hukum, berbagai pelanggaran hukumyang terjadi di masyarakat (berita tentang pembunuhan, kekerasan atau penganiayaan, kecelakaan lalulintas, korupsi, pencurian, penipuan, membangun tanpa izin, sengketa hak dll), tidak kalah penting fungsi pers menyampaikan informasi kepada publiktentang proses hukum yang sedang berjalan di dalam atau diluarproses peradilan (seperti arbitase) dan (yang saat ini kasus yang masih hangat-hangatnya, sebagai contoh kasus Jesica, dan kasus narkoba Gatot / ketua umum Farfi). 
3. Pers sebagai penghambat penegakan hukum, kita menganal ungkapan trial by the press (peradilan oleh pers). Ungkapan ini menggambarkan, pers melalui pemberitaan atau rubrik opini publik, atau opini pers sendiri, pers telah memiliki pendapat umum hukum atau sekurang-kurangnya mendorong publik berpendapat mengenai suatu perkara yang belum diputus pihak yang berwewenang (pengadilan atau diluar pengadilan). Cara-cara pemberitaan atau penyampaian opini, semacam ini tidak hanya melanggar asas praduga tidak bersalah (merugikan pihak-pihak yang "dikalahkan" juga diduga pelaku pidana, melanggar asas presumption of innocence), melainkan juga merupakan suatu bentuk menghambat proses peradilan yang adil, fair, dan imparsialbahkan merupakan pelecehan terhadap tatanan peradilan. Lebih jauh dapat dicatat, segala bentuk yang dapat digolongkan sebagai trial by the press, abstruction of justice, atau contempt of court, dengan maksud mempengaruhi hakim, merupakan pelanggaran terhadap asas menjamin independensi hakim, peradilanyang fair, imparsial untuk memutus suatu perkara secara benar, tepat dan adil.

4. Kemerdekaan pers dan kekuasaan kehakiman yang merdeka (kebebasan hakim) Kemerdekaan (kebebasan) pers dalam masyarakat yang mendambakan demokrasi, menjunjung tinggi hak asasi, dan masyarakat yang mendambakan kemajuan, dipandang sebagai sebuah kemestian. Menurut American pers comission : kebebasan pers merupakan sesuatu yang esensial untuk kebebasan politik. Ketika seseorang tidak dapat secara bebas menyampaikan pikirannya kepada orang lain, maka tidak akan ada jaminan kebasan. Apabila ada kebbasan berekpresi, berarti suatu permulaan kehadiran suatu masyarakat bebas dan itu berarti bahwa telah ada semua hak atas kebebasan.

Kebebasan Pers adalah bagian dari hak azasi manusia yang harus diakui dan dilindungi dalam konstitusi. Penyebutan secara eksplisit ini sangat penting, dan dimaksudkan agar pemerintahatau parlemen yang melaksanakan konstitusi tidak seenaknya menjabarkan perlindungan kemerdekaan pers sesuai dengan politik hukum penguasa saat itu.Seperti sudah disebutkan di atas, Undang-undang Pers diundangkan pada tahun 1999 (UU/40/1999 tentang Pers) sedangkan Komisi Konstitusi baru pada akhir April 2004 menyetujui dimasukkannya perlindungan negara atas kebebasan Pers di dalam Undang-udang 1945. Undang-undang Pers menggunakan istilah kemerdekaan Pers, dan Komisi Konstitusi menggunakan istilah kebebasan Pers. Dapat disimpulkan, bahwa sebenarnya tidak ada perbedaan prinsip antara istilah kemerdekaan Pers dengan istilah kebebasan Pers. Istilah yang dipergunakan secara normatif adalah kemerdekaan Pers, tetapi dalam bahasa lisan, lebih suka digunakan istilah kebebasan Pers. Kemerdekaan Pers adalah kebebasan Pers, dan sebaliknya kebebasan Pers adalah kemerdekaan Pers. Kemerdekaan Pers dijamin sebagai hak asasi warga negara, tidak dikenakan penyensoran, pembredelan atau pelarangan penyiaran, dan sebagai jaminan kemerdekaan Pers, Pers nasional mempunyai hak mencari, memperoleh, dan menyebarluaskan gagasan dan informasi. Kemerdekaan Pers dengan demikian akan disebutkan secara eksplisit dalam Pasal 28 huruf G Undang-undang 1945, dan dalam Undang-undang Pers

\subsection{Tanggung Jawab Pers dan Kode Etik Jurnalistik}




\section{Tanggung Jawab Pers}

Pasca reformasi politik 1988, kebabasan pers dibuka selebar-lebarnya berbeda dengan masa orde baru, ketika kebebasan pers masih bersifat semu, pers menjadi salah satu kekuatan yang sangat berpengaruh dimasyarakat, yang didukung revolusi besar-besaran dibidang teknologi, pers dengan sangat mudah dan luar biasa cepat menyalurkan berita ke seluruh elemen masyarakat. Impian oleh para praktisi atau dunia pers untuk menggenggam dan menguasai dunia, kini dapat menjadi kenyataan. Kalangan pers dengan sangat cepat berhitung tentang kekuatan, mereka mampu mengantisipasi bagaimana pembentukan opini melalui berita-berita dilancarkan masyarakat yang dituju, lantas menghitung imbas politik dan finansial yang akan mereka terima. Kalangan pers dan praktisi nedia dengan lihai membaca peluang untuk meyakinkan semua elemen bahwa kini giliran pers dan media massa lain yang naik tahta. Ampuh dan kuatnya kekuatan media massa dimasyarakat, membuatnya memang harus diperhitungkan oleh siapapun. Berbeda dengan masa-masa sebelumnya (masa penjajahan, demokrasi terpimpin (orde lama), dan orde baru) pers dan media massa lain telah merasakan kemerdekaan dan kebebasan dalam arti sesunguhnya, tidak lagi bersifat semu.

Imbangan terhadap kebebasan pers adalah tanggung jawab dalam pelaksaan fungsi, kewajiban, hak, dan peranan pers, seperti tertuang dalam pasal $5 \mathrm{UU} / 11 / 1966$ yang diubah dan disempurnakan oleh UU/04/1967 dan UU/21/1992 paal, 2, 3, 4 dan 5. Fungsi kewajiban dan hak pers itu, dalam UU/11/1966 pada pasal 2 (1) disebudkan bahwa pers nasional adalah alat revolusi dan merupakan massa, media yang relatif aktif, dinami, kreatif, informatoris, dan mempunyai fungsi kemasyarakatan pendorong dan pemupuk daya pikiran kritis dan progresif meliputi segala perwujudan kehidupan masyarakat Indonesia. Kewajiban pers nasional pasal 2 (2) Undang-undang Nomor 11 tahun 1966 adalah sebagai berikut :

1. Mempertahankan, membela, mendukung dan melaksanakan Pancasila dan Undang-undang Dasar 1945 secara murni dan konsekwen.

2. Memperjuangkan pelaksanaan amanat penderitaan rakyat berlandaskan demokrasi pancasila.

3. Memperjuangan kebenaran dan keadilan atas dasar kebebasan pers.

4. Membina persatuan dan kekuatan-kekuatan progresif revolusioner dan perjuangan menentang imperialisme, kolonialisme, neokolonialisme, feodalisme, liberalisme, komunisme dan fasisme/diktator.

5. Menjadi penyalur pendapat umum yang konstruktif dan progresif revolusioner.

Pasal 3 UU/11/1966 menjelaskan bahwa pers mempunyai hak kontrol, kritik dan koreksi yang bersifat korektif dan konstruktif. Sejak ditetapkannya UU/11/1966 diatas, pers dituntut untuk menjadi motivatordalam mencerdaskan kehidupan bangsa. Pers dalam hal ini mempunyai fungsi edukatif, meskipun pada masa lalu menjadi titik tekan, pers tetap diperbolehkan untuk selalu menggunakan haknya, yaitu hak kontrol, kritik, dan koreksi. Dalam hal ini, pers dapat menjadi the power of balance di tengah-tengah semangat yang menggebu untuk perjuangan menentang imperialisme, kolonialisme, neokolonialisme, feodalisme, liberalisme, komunisme dan fasisme/diktatur. Dalam mewujudkan kemerdekaan pers, wartawan Indonesia 
menyadari adanya tanggung jawab sosial serta keberagaman masyrakat ${ }^{5}$. Pers sangat diperlukan sesuai dengan fungsinya, baik bagi seseorang, organisasi, lembagamaupun institusi, tidak hanya untuk memperoleh informasi tetapi lebih dari itu karena pers dapat membentuk opini masyarakat ${ }^{6}$. yang menyebabkan pers memegang peranan penting dalam kehidupan masyarakat, fungsi mempengaruhi dari surat kabar secara implisit terdapat pada tajuk rencana dan artikel7.

\section{Kode Etik Jurnalistik}

Pasal 7 angka 2 Undang-undang Nomor 40 Tahun 1999 Tentang Pers menerangkan, wartawan memiliki dan menaati Kode Etik Jurnalistik. Menindaklanjuti mengenai Kode Etik Jurnalistik ini, Dewan Pers telah mengeluarkan peraturan Dewan Pers Nomor 6/Peraturan-DP/V/2008 tentang Pengesahan Surat Keputusan Dewan Pers Nomor 03/SKDP/III/ 2006 tentang Kode Etik Jurnalistik Sebagai Peraturan Dewan Pers. Dalam lampiran peraturan Dewan Pers tersebut dikatakan :

Kemerdekaan berpendapat, berekspresi dan pers adalah hak asasi manusia yang dilindungi Pancasila, Undang-undang Dasar 1945, dan deklarasi Universal Deklarasi Universal Hak Asasi Manusia PBB. Kemerdekaan Pers ialah sarana masyarakat untuk memperoleh informasi dan berkomunikasi, guna memenuhi kebutuhan hakiki dan meningkatkan kualitas kehidupan manusia. Dalam mewujudkan kemerdekaan per situ, wartawan Indonesia juga menyadari adanya kepentingan bangsa, tanggungjawab social, keberagaman masyarakat dan norma-norma agama. Dalam melaksanakan fungsi, hak, kewajiban dan peranannya, pers menghormati has asasi setiap orang, karena itu pers dituntut professional dan terbuka untuk dikontrol oleh masyarakat. Untuk menjamin kemerdekaan pers dan memenuhi hak publicmemperoleh informasi yang benar, wartawan Indonesia memerlukan landasan moral dan etika profesi sebagai pedoman operasional dalam menjaga kepercayaan public dan menegakan integeritas serta profesionalisme. Atas dasar itu, wartawan Indonesia menetapkan dan menaati Kode Etik Jurnalistik.Selanjutnya dalam pasal 1 Kode Etik Jurnalistik dikatakan, wartawan Indonesia bersikap independen, menghasilkan berita yang akurat, berimbang, dan tidak beritikad buruk. Penafsiran pasal ini menguraikan :

a. Independen, berarti memberitakan peristiwa atau fakta sesuai dengan suara hati nurani tanpa campur tangan, paksaan, dan intervensi dari pihak lain, termasuk pemilik perusahaan pers.

b. Akurat, berarti bias dipercaya benar, sesuai dengan keadaan objektif ketika peristiwa terjadi.

c. Berimbang, berarti semua pihak mendapat kesempatan setara.

Tidak beritikad buruk, berarti tidak ada niat secara sengaja untuk menimbulkan kerugian pihak lain

${ }^{5}$ Surat Keputusan Dewan Pers No. 1/SK-DP/2000 tentang Kode Etik Wartawan Indonesia (KEW!), Dewan Pers, hal. 17

${ }^{6}$ Muldjohardjo, (2003), Delik Pers Di Dalam Praktek dan Faktor-Faktor Yang Mempengaruhlnya,

Media Hukum, Persatuan Jaksa Republik Indonesia, Vol. 1 No. 4, Jakarta, hlm. 22

${ }^{7}$ Onong Uchyana Effendy, op.cit., hal 150 


\section{Kesimpulan}

Adapun kesimulan dari artiel ini antara lain:

a. Pers merupakan pilar demokrasi keempat setelah eksekutif, legislatif dan yudikatif, pers sebagai kontrol atas ketiga pilar itu dan melandasi kinerjanya dengan check and balance. untuk dapat melakukan peranannya perlu dijunjung kebebasan pers dalam menyampaikan informasi publik secara jujur dan berimbang. disamping itu pula untuk menegakkan pilar keempat ini, pers juga harus bebas dari kapitalisme dan politik. pers yang tidak sekedar mendukung kepentingan pemilik modal dan melanggengkan kekuasaan politik tanpa mempertimbangkan kepentingan masyarakat yang lebih besar, dan telah termuat dalam lampiran Peraturan Dewan Pers Nomor : 5/Peraturan-DP/IV/2008 tentang Perlindungan Profesi wartawan.

b. Karena kebebasan Pers bukan mutlak untuk pers semata, melainkan untuk menjamin hak-hak masyarakat untuk memperoleh informasi, namun dalam prakteknya masih terdapat hambatan-hambatan yang terjadi dalam rangka mewujudkan kebebasan pers seperti yang terkandung dalam UU/040/1999 tentang Pers. Kebebasan berpendapat yang didasarkan pada pasal 28 UUD 1945, kebebasan pers di Indonesia pada saat ini diatur dalam UU/040/1999 yang dalam isi-isi dalam pasal berpedoman pada pasal 28 UUD 1945, namun dalam prakteknya masih banyak hambatan untuk menuju kebebasan pers yang sesuai dengan UU/040/1999, hambatan-hambatan tersebut bisa berasal dari masyarakat, Pemerintah dan bahkan dari unsur pers sendiri. Setelah disyahkannya UU/040/1999 tentang Pers tidak semata-mata membawa pengaruh positip bagi pers nasional, dan ternyata Undang-undang ini juga membawa pengaruh negatip dengan dasar kebebasan yang tidak terkontrol dan cenderung berlebihan.

\section{Daftar Pustaka}

Idri Shaffat (2008), Kebebasan tanggung jawab dan penyimpangan Pers, Prestasi Pustaka, Jakarta.

Deddy Ismatullah (2014), Pengantar Hukum Indonesia, Bandung, Pustaka Setia. Manan, Bagir, (2016), Buku Saku Wartawan, Jakarta, Dewan Pers. . (2016), Pers Hukum, dan Hak Asasi Manusia, Jakarta Dewan Pers.

Raharjo Handri, (2016), Sistem Hukum Indonesia, Yogyakarta ,Pustaka Yustisia, Undang-Undang Dasar Negara Republik Indoinesia

Undang-Undang Republik Indonesia Nomor 40 Tahun 2007 tentang Perseroan Terbatas.

Peraturan Dewan Pers Nomor : 5/Peraturan-DP/IV/2008 tentang Perlindungan Profesi wartawan.

Henry Chambel Black, Black Law Dictionary, St. Paul, Minn : West Publishing Co.

Muldjohardjo, (2003) Delik Pers Di Dalam Praktek dan Faktor-Faktor Yang Mempengaruhlnya, Media Hukum, Persatuan Jaksa Republik Indonesia, Vol. 1 No. 4, Jakarta. 
Onong Uchyana Effendi, (2002), Ilmu Komunikasl (Teori dan Praktek), Bandung, Remaja Rasdakarya, Cet, XVI.

Surat Keputusan Dewan Pers No. 1/SK-DP/2000 tentang Kode Etik Wartawan Indonesia (KEW!), Dewan Pers. 